\title{
Facing challenges in an ageing world
}

\author{
Guillermo López-Lluch $(\mathbb{D} \cdot$ Suresh I. S. Rattan
}

Received: 27 July 2015/Accepted: 28 July 2015/Published online: 4 August 2015

(C) Springer Science+Business Media Dordrecht 2015

The 9th European Congress of Biogerontology (9th ECB), under the auspice of the International Association of Gerontology and Geriatrics- European Region (IAGG-ER), was held in Sevilla, Spain, 16-18 October, 2014. This special issue of Biogerontology includes 9 papers selected from more than 67 lectures and abstracts presented at the Congress, from participants from 14 countries worldwide (see book of abstracts at: http://upo.es/9ECB/). The theme of the congress "Facing Challenges in an Ageing World", covered a wide range of topics from molecular basis to epidemiological aspects of the ageing populations and novel ageing interventions. What follows is a brief commentary on the papers published in this special issue.

The relationship between genes and life-style as determinant of longevity is discussed by Irene Maeve Rea and colleagues (Rea et al. 2015), in a series of

G. López-Lluch ( $₫)$

Department of Physiology, Anatomy and Cell Biology, Centro Andaluz de Biología del Desarrollo (CABD-CSICJA), CIBERER, Instituto de Salud Carlos III, Universidad Pablo de Olavide, Carretera de Utrera Km. 1,

41013 Seville, Spain

e-mail: glopllu@upo.es

\section{S. I. S. Rattan}

Department of Molecular Biology and Genetics, Aarhus University, Gustav Wieds Vej 10C, 8000 Aarhus-C,

Denmark

e-mail: rattan@mbg.au.dk studies performed with a group of nonagenarians in Belfast (UK). Interestingly, this study shows the themes selected by the nonagenarians themselves as important pointers in their age-span and health-span. The importance of diet in longevity is reviewed in the work of José Villalba group (Villalba et al. 2015) highlighting that a protected membrane environment enriched in monounsaturated fatty acids is essential in healthspan and longevity. Two review articles discuss the complex function of mitochondria in ageing. For example, the group of Giuseppe Passarino from Calabria, Italy (D'Aquila et al. 2015) presents the important role of mitochondrial epigenetics in ageing. This work summarizes the involvement of mitochondrial function and the communication between mitochondria and nucleus in the regulation of nuclear epigenome and the role of epigenetic modifications in the mitochondrial DNA. On the other hand, LópezLluch and colleagues show a compilation of the studies performed in mitochondria of different organisms. The accumulation of damaged mitochondria during aging increases ROS production and oxidative damage but the induction of mechanisms involved in mitochondrial turnover, increasing biogenesis at the same time that induces the elimination of damaged mitochondria through mito/autophagy, increases mitochondrial efficiency and reduces ROS-dependent damage. Many hormetins such as calorie restriction, resveratrol and other bioactive compounds and 
physical activity activate the molecular pathways involved in this mitochondrial turnover (López-Lluch et al. 2015).

Several original research articles included in this special issue present different aspects of the activity of antioxidants or bioactive compounds in blood (Jansen et al. 2015; Capeleto et al. 2015), the gender importance in fat accumulation during ageing (Castillo et al. 2015), and the importance of the immune system during ageing (Campos et al. 2015; Di Benedetto et al. 2015).

Changes in the activity of the immune system are deeply associated with ageing. For this reason, this topic was treated in a specific section in the 9th ECB. Two papers included in this issue show different aspects of the evolution of the immune system during ageing. Rafael Solana's group from Córdoba, Spain, studies the expression of different natural killer (NK) activating receptors in the different $\mathrm{NK}$ cell subsets in order to understand the deterioration of these cells during ageing (Campos et al. 2015). Graham Pawelec's group from Tübingen, Germany, discusses the impact of age, sex and CMV-infection on T cells (Di Benedetto et al. 2015). The study of these factors on T cells from participants in the Berlin Aging Study II (BASE-II) demonstrated differences in the frequency of naïve $\mathrm{CD}^{+}$cells (effectors) dependent on age and sex and CMV-infection.

Acknowledgments As president of the Organizing Committee of the 9th European Congress of Biogerontology Dr. LópezLluch wishes to acknowledge the help and collaboration of all the people involved in the organization of this event and especially to the group of Cell Biology at the Centro Andaluz de Biología del Desarrollo because without their work the organization of this congress would be impossible. Furthermore, the sponsorship of the following contributors made possible the meeting: Universidad Pablo de Olavide, Centro Andaluz de Biología del Desarrollo, Springer Publishers, International Coenzyme Q10 Association, Sociedad Española de Biología Celular, Universidad Internacional de Andalucía, Junta de Andalucía, Cien por Cien Natural, Pharma Nord Denmark, C. Viral, ThermoFisher Scientific and Cultek.

\section{References}

Campos C, López N, Pera A, Gordillo JJ, Hassouneh F, Tarazona R, Solana R (2015) Expression of NKp30, NKp46 and DNAM-1 activating receptors on resting and IL-2 activated NK cells from healthy donors according to CMV-serostatus and age. Biogerontology. doi:10.1007/s10522-0159581-0

Capeleto D, Barbisan F, Azzolin V, Dornelles EB, Rogalski F, Teixeira CF, Machado AK, Cadoná FC, da Silva T, Duarte T, Duarte MM, da Cruz IB (2015) The anti-inflammatory effects of resveratrol on human peripheral blood mononuclear cells are influenced by a superoxide dismutase 2 gene polymorphism. Biogerontology. doi:10.1007/ s10522-015-9561-4

Castillo C, Carnicero JA, de la Torre MÁ, Amor S, GuadalupeGrau A, Rodríguez-Mañas L, García-García FJ (2015) Nonlinear relationship between waist to hip ratio, weight and strength in elders: is gender the key? Biogerontology. doi:10.1007/s10522-015-9582-z

D’Aquila P, Bellizzi D, Passarino G (2015) Mitochondria in health, aging and diseases: the epigenetic perspective. Biogerontology. doi:10.1007/s10522-015-9562-3

Di Benedetto S, Derhovanessian E, Steinhagen-Thiessen E, Goldeck D, Müller L, Pawelec G (2015) Impact of age, sex and $\mathrm{CMV}$-infection on peripheral $\mathrm{T}$ cell phenotypes: results from the Berlin BASE-II Study. Biogerontology. doi:10.1007/s10522-015-9563-2

Jansen E, Beekhof P, Tamosiunas A, Luksiene D, Baceviciene M (2015) Biomarkers of oxidative stress and redox status in a short-term low-dosed multivitamin and mineral supplementation study in two human age groups. Biogerontology. doi:10.1007/s10522-015-9568-x

López-Lluch G, Santos-Ocaña C, Sánchez-Alcázar JA, Fernández-Ayala DJ, Asencio-Salcedo C, Rodríguez-Aguilera JC, Navas P (2015) Mitochondrial responsibility in ageing process: innocent, suspect or guilty. Biogerontology. doi:10.1007/s10522-015-9585-9

Rea JN, Carvalho A, McNerlan SE, Alexander HD, Rea IM (2015) Genes and life-style factors in BELFAST nonagenarians: nature. Nurture and Narrative. Biogerontology. doi:10.1007/s10522-015-9567-y

Villalba JM, López-Domínguez JA, Chen Y, Khraiwesh H, González-Reyes JA, Del Río LF, Gutiérrez-Casado E, Del Río M, Calvo-Rubio M, Ariza J, de Cabo R, López-Lluch G, Navas P, Hagopian K, Burón MI, Ramsey JJ (2015) The influence of dietary fat source on liver and skeletal muscle mitochondrial modifications and lifespan changes in calorie-restricted mice. Biogerontology. doi:10.1007/s10522015-9572-1 